Notre Dame Law School

NDLScholarship

Journal Articles

Publications

2012

\title{
The Catholic Church, Human Rights, and Democracy: Convergence and Conflict with the Modern State
}

Paolo G. Carozza

Notre DameLaw School, pcarozza@nd.edu

Daniel Philpott

Follow this and additional works at: https://scholarship.law.nd.edu/law_faculty_scholarship

Part of the Human Rights Law Commons

\section{Recommended Citation}

Paolo G. Carozza \& Daniel Philpott, The Catholic Church, Human Rights, and Democracy: Convergence and Conflict with the Modern State, 15 Logos: A J. Catholic Thought \& Culture 15 (2012).

Available at: https://scholarship.law.nd.edu/law_faculty_scholarship/882 


\section{The Catholic Church, Human Rights, and Democracy}

\section{Convergence and Conflict with the Modern State}

In Pope Benedict XVI's address to the Roman Curia of December 2 2, 2006, he made reference to the Catholic Church's own journey toward embracing human rights and religious freedom. ${ }^{1}$ Perhaps surprisingly to some, he gave credit for this development to the Enlightenment, which he said could count human rights and religious freedom as its "true conquests." More predictably to most, he reiterated his longstanding criticism of the Enlightenment's attempt to ground these principles on positivist and skeptical foundations. He argued rather that a constructive synergy of faith and reason was the best foundation for tolerance, human rights, and the preservation of religious freedom.

Benedict's thesis points to an ambivalent historical relationship between the social teachings of the Catholic Church and modern political institutions based on human rights and democracy. It is in part a story of convergence. Gradually, over the course of the twentieth century, then far more rapidly beginning with the Second Vatican Council, following upon several centuries of consistent resistance to the momentum of European politics, the Church came to embrace norms of human rights and democracy reflective of those 
that appeared in international instruments like the UN Charter and the Universal Declaration of Human Rights as well as the constitutions of western democracies. As the term convergence-rather than accommodation or adaptation - suggests, the Church did not simply conform itself to what others had long before pioneered. True, as Benedict argues, a dialogue with the Enlightenment did beget Catholic evolution in certain dimensions of rights, especially religious freedom. But it is also the case, as we point out below, that the Church has articulated a tradition of rights since as early as the sixteenth century. For its own part, the state and the "international society" of states had to evolve, too. The sovereign states system signified by the Peace of Westphalia in I 648 clearly evaded the accountability that human rights and democracy demand. The French Revolution and its liberal republican legatees in Europe and Latin America propounded a portfolio of rights, to be sure, but with prominent lacunae, particularly in the case of the religious freedom of the Catholic Church. Indeed, the Church's own willingness to embrace religious freedom at Vatican II arose in part from the assurance that post-World War II Western European democracies as well as the US Constitution provided that the Church could be free under a liberal democratic constitution.

But the long rapprochement between the Church and modern norms of human rights and democracy is neither complete nor uncontested. After Vatican II, tensions between the Church and modern states and international institutions did not disappear; ongoing clashes included the Church's complex confrontation with authoritarian states and its fracases with democracies over abortion, divorce, fetal research, euthanasia, war, and other issues, with the UN overpopulation policy, and with the European Union over Europe's Christian identity and its policies on the family and sexuality.

This article argues that the Catholic Church's relationship to human rights and democracy in the modern world can only be understood through both of the above dynamics: a historical convergence and the persistence of tension. The first half of the article argues for 
this dual theme in the doctrines of the Church, where today, as over the past several centuries, the Catholic conception of the common good yields both an embrace of human rights and democracy and a critique of their secular espousal. The second half of the article focuses on practice, showing how the Church's efforts to advance its teachings on human rights and democracy sometimes succeed and sometimes encounter resistance, both on account of conceptual differences with modern states and international organizations as well as problems rooted in institutional realities. Doctrine and practice are not hermetically separable, but they are distinct enough for our analysis. Both realms, we argue, manifest historical convergence as well as ongoing ambivalence.

\section{Sovereignty, Human Rights, and Democracy in the Teaching of the Church}

A systematic theoretical foundation for both international law and universal human rights emerged in Catholic thought at least as early as the sixteenth century in the work of Francisco de Vitoria and his contemporaries in Salamanca, Spain. The classical natural law account characteristic of the Catholic intellectual tradition has consistently understood the paradigmatic definition of law to be tied to the good of the human person through law's proper orientation to the common good. ${ }^{2}$ Out of his deep reflections on the Spanish encounter with the peoples of the New World, Vitoria expanded the Thomistic notion of the common good to incorporate into it the ius gentium, the law of nations. Vitoria analogized the whole world to a single commonwealth, in which all of the human family shares in a single common good. ${ }^{3}$ Synthesizing the juridical concepts of rights drawn from the canon law with the philosophical tradition of natural law, Vitoria and his followers also vigorously and systematically defended the rights of the American Indians to ownership of their lands, to equality, and to sovereignty, principally on the basis that the natural rights of the Indians were grounded in their creation 
as rational beings in God's image. ${ }^{4}$ The School of Salamanca thus represents an early and lucid example of Catholic human rights discourse. Confirmed by the papal magisterium in multiple instances, these doctrines regarding the unity of the human family and the rights of all of God's children were not at all on the fringe of the teaching of the Church as a whole. ${ }^{5}$

As these nascent ideas of international law and natural rights developed over the ensuing centuries, they differed in certain critical ways, in root and branch, from those notions of international legal order and human rights that came to dominate political and legal thought in the modern era. With respect to international law, the Westphalian system that emerged from the mid-seventeenth century onward was premised on the sovereignty of the territorial state. This was understood by many to contradict the Catholic Church's traditional teaching that political authority came "from God alone" (and indirectly, therefore, from the universal temporal authority of the Church itself). Pope Innocent X, for example, condemned the treaties of Westphalia as "null, void, invalid, iniquitous, unjust, damnable, reprobate, inane, empty of meaning and effect for all time." As territorial sovereignty gave rise to legal nationalism and positivism in the eighteenth and nineteenth centuries, the gap widened between the traditional Catholic understanding of the law of nations, grounded in the responsibility of rulers for the universal common good, and secularized international law, increasingly grounded in sovereign autonomy and consent.

Similarly, from the perspective of the classical natural law tradition, the natural rights theories of Hobbes, Locke, and Rousseau shared a common reduction of the ends of human life and of politics. Understanding man as naturally solitary and antagonistic, they conceived of rights as emerging primarily from the instinct for physical self-preservation and need for security. At its core, this view diverged dramatically from the preexisting Catholic conception of rights as expressions of the human unity and dignity that flow from being created in the likeness of God. 
The contrast between the two traditions came to the fore concretely with the French Revolution and the nineteenth century conflict between the Church and modern European liberalism. Although it advanced various "Rights of Man," the French Revolution also sharply attacked the authority of the Church, requiring priests to sign an oath of loyalty and taking the lives of many who refused. ${ }^{8}$ In the nineteenth and early twentieth centuries, the Revolution's anticlericalism lived on in liberal republican movements in Western Europe and Latin America, as well as in German Chancellor Otto von Bismarck's Kulturkampf and in international socialism, all of which sought to truncate the Church's rights, authority, and influence in civil society, especially in education.

Fueling this conflict from the other direction was the Church's own continued adherence to a theory of politics that it had developed in the Middle Ages, one holding that at least in countries where Catholics constitute a majority of the population, Catholicism ought to be established as the religion of the realm while other faiths ought to be restricted. The Church's doctrines thus forbade certain crucial aspects of liberalism, including religious freedom and freedom of expression. ${ }^{9}$

For both of those reasons, in its struggle with modern European states throughout the nineteenth century, the Church's teachings on natural rights were emphatically focused on the condemnation of what the Church saw as the false premises of liberalism. The primary target of criticism was the view of man as fundamentally autonomous, naturally free in an absolute sense that denied human beings' structural dependence on God and their intrinsically social nature. This assertion of unqualified liberty, without regard to truth, was seen to result in excessive individualism, in the privatization and suppression of religion, and ultimately in the absolutism of the state subject to no higher authority. Consistently, the French Declaration of the Rights of Man and specific rights such as freedom of the press were condemned in magisterial pronouncements as manifestations of what Pius VI called the "monstrous right" of absolute liberty. ${ }^{10}$ 
Only with the papacy of Leo XIII in the late nineteenth century do we see a greater convergence, or at least mutual engagement, between Catholic principles of human rights and the ideas common to secular political models. Like the other nineteenth century popes before him, Leo XIII taught that a notion of rights severed from the authority of God could confuse truth and falsehood and would ultimately place natural rights at the mercy of the changing whims of human legislators. Unlike his immediate predecessors, however, he went on to retrieve a different vocabulary of rights from within the tradition of the Church. Leo XIII affirmed in particular the right to marriage, the right to education, the right of association (especially associations of workers), the right to private property, and "the right of procuring the things which sustain life." He dealt with the relationship of rights to the common good and of rights to duties, and other systematic, foundational questions of human rights. ${ }^{11}$ Leo XIII thus proposed a robust alternative to the liberal conception of rights by renewing and adapting the tradition to the new material conditions of mankind in the modern world.

In the context of totalitarian dictatorship and world war in the I 930 s and I 940s, Popes Pius XI and Pius XII continued Leo's affirmation of certain basic rights and stressed their grounding in the dignity of the person. ${ }^{12}$ By I 948 , Catholic teachings on rights were well developed enough to exert an indirect but significant influence on the Universal Declaration of Human Rights. ${ }^{13}$

As with human rights, Leo XIII and his successors, especially Benedict XV, the "peace Pope" of the World War I years, ${ }^{14}$ as well as Pius XI and Pius XII, also opened the door to a greater acceptance of the realities of the modern state and states system. With respect to international law and institutions, Pius XII openly supported the work of the Dumbarton Oaks conference and the San Francisco conference that created the United Nations. ${ }^{15}$ Again, as with human rights, however, this endorsement was rooted in the Church's longstanding teachings about the universal common good, not in the idea of absolute, autonomous sovereignty. ${ }^{16}$ 
By contrast, the Church's judgment of democracy was far more uncertain. Prior to the twilight of the nineteenth century, popes spoke about democracy rarely and usually vitriolically, linking it to liberalism and socialism. ${ }^{17}$ Then, paralleling his development of the ideas of human rights and international society, Leo XIII began to discuss democracy more favorably, though still qualifiedly. Affirming that the Church is in principle neutral with respect to regime structure, he allowed that a majority might choose who will exercise authority for the common good, but stressed, importantly, that "this choice decides who will be sovereign but does not confer the rights of sovereignty. The authority is not constituted [by the majority's choice]; rather, it is decided who will exercise it." ${ }^{\prime 18}$ In the mid-twentieth century, Pius XII endorsed democracy even more positively, but with similar reservations. In his I 944 Christmas message, he, too, abstained from sacralizing one particular form of regime, but condemned state absolutism, blaming it for the aggression and corruption that engulfed the world in war, and spoke favorably of the strengthened spirit of democratic freedom and participation that was to emerge after the war's end. He even declared democratic government "a postulate of nature imposed by reason itself." A contradiction to the claim that no one regime form is enduringly valid? Only when considered apart from his praise for "the democratic ideal of liberty and equality," thus linking democracy to what popes have indeed taught is enduringly valid: human rights. ${ }^{19}$ Like popes before and after him, though, he continued to insist that even democratic rule derives its authority from its orientation to the common good and that it can lose its authority insofar as it becomes "the arbitrariness of the mass."

The same combination of commitments - support for international institutions, skepticism of absolute sovereignty, and human rights and democracy insofar as they instantiate the Church's notion of the common good-redounded in the Church's contemporaneous support for another, innovative form of institution: European federation, launched initially as the European Coal and Steel Com- 
munity with the Treaty of Paris in 1951. The founding fathers of the union were predominantly devout Catholics, including France's Robert Schuman and (to a lesser extent) Jean Monnet, ${ }^{20}$ Italy's Alcide de Gasperi, and Germany's Konrad Adenauer; the federation's most supportive political parties were (mostly) Catholic-inspired Christian Democratic ones; and Pope Pius XII supported this founding enthusiastically. Precisely the political morality that we have been discussing explains this support. The nascent European federation represented a resurrection of the Church's medieval vision of a morally and politically united European civilization, though now updated with modern notions of human rights and democracy. Through these institutions, shortly to become the European Economic Community and decades later the European Union, Westphalia was reversed. Over the course of its history, European integration consistently garnered its strongest support from Christian Democratic parties and disproportionately strong support from Catholic voters. ${ }^{21}$

In the following decade, Pope John XXIII continued and expanded the Church's commitments to human rights, democracy, and international institutions even while vigilantly stressing differences between Catholic and secular understandings of these ideals. In his I 963 encyclical, Pacem in Terris, ${ }^{22}$ he praised the Universal Declaration of Human Rights as "an act of the highest importance." Drawing on the Catholic natural law tradition, he affirmed among the universal and inviolable rights of every person not only such rights as life, property, association, and education - rights recognizable by classic liberal theory — but also the right to follow one's conscience in honoring God, the right to work suited to one's capacities, and the right to form and belong to intermediate groups in society. John departed even more strikingly from parallel, secular human rights ideas by identifying the true and ultimate aim of human rights to be the formation of our relationship with God and our destiny in beatitude, as opposed to the illusion of an "autonomous self." By contrast, he did not develop as clearly the Church's teaching on democracy. 
For international bodies, especially the United Nations, John lent a stronger papal endorsement than any previous pope. In light of increasing interdependence and growing association among human communities, "no state can fittingly pursue its own interests in isolation from the rest," he averred. Observing that "the unity of the human family ... consists of men who are all equal by virtue of their natural dignity," he gave strong support to the creation and maintenance of international structures with responsibility for the "universal common good; the good, that is, of the whole human family."

In the contemporaneous documents of Vatican II (1962-65) one can find a similar approach to human rights and modern political systems. The Council's single most important departure from the Church's earlier, medieval model of political authority was Dignitatis Humanae, which declared religious liberty a basic right rooted in the God-given dignity of the person - a right meant to protect both the practice of other faiths as well as the Church's own rights in settings where it was threatened. ${ }^{23}$

The Council's Pastoral Constitution on the Church in the Modern World, Gaudium et Spes, did not refer to "democracy" as such, but rejected despotic governments, affirmed the freedom of people to choose their type of government and their leaders, and appealed to the importance of political participation, which in turn it said required the rule of law and separation of powers. ${ }^{24}$ True to tradition, the document endorsed human rights far more strongly and explicitly. By that time, though, the political landscape of the world meant that to endorse human rights was effectively to endorse democracy since human rights were realized most effectively in states with democratic constitutions. ${ }^{25}$ Finally, Gaudium et Spes continued and extended the Catholic tradition of viewing the common good as worldwide in scope, and stressed repeatedly that international solidarity, coordination, institutions, and law are necessary to secure peace, development, and human rights.

In his own encyclicals, Paul VI embraced the call for international solidarity to secure justice and rights, extending it in a par- 
ticular way to questions of concern to the poorer regions of the world and to the problem of economic development. ${ }^{26}$ It is worth noting also that his encyclical on the eightieth anniversary of Leo XIII's Rerum Novarum appeared to depart from the Church's earlier, formally neutral stance with respect to forms of government, and instead argued that "to counterbalance increasing technocracy, modern forms of democracy must be devised, not only making it possible for each man to become informed and to express himself, but also by involving him in a shared responsibility." 27

An even fuller integration of human rights, democracy, and international solidarity under the rule of law would take place in the extensive writings of Blessed John Paul II. He gave the idea of human rights an unprecedented breadth and centrality in Catholic social teaching, from his first encyclical, which expressed the hope that "human rights will become throughout the world a fundamental principle of work for man's welfare," to his last addresses. ${ }^{28}$ In his speech to the General Assembly of the United Nations on the occasion of the fiftieth anniversary of the United Nations, for example, John Paul remarked that "there are indeed universal human rights, rooted in the nature of the person, rights which reflect the objective and inviolable demands of a universal moral law," and he described the r 948 Universal Declaration of Human Rights as "one of the highest expressions of the human conscience of our time."29

And yet John Paul's reflections on human rights also preserved and even heightened a tension that we have been tracing throughout this brief history. He criticized severely certain claims for rights that are grounded in radically different understandings of human anthropology. In Evangelium Vitae, for example, he decried modern culture's tendency to characterize crimes against life as exercises of human rights. ${ }^{30}$ "How can we reconcile these declarations [of human rights] with the refusal to accept those who are weak and needy, or elderly, or those who have just been conceived?" he asked. "These attacks . . . represent a direct threat to the entire culture of human rights. It is a threat capable, in the end, of jeopardizing 
the very meaning of democratic coexistence." This contradiction is not new. Although John Paul is addressing a different set of social circumstances, his ambivalence toward human rights in the modern state arises out of the same understandings of the origin and ends of human life that have historically characterized Catholic thought on natural rights.

In that same I 995 UN address in which he lauded the Universal Declaration of Human Rights, John Paul called for an equal attention to and respect for the "rights of nations" in the international order, "which are nothing but 'human rights' fostered at the specific level of community life," but he takes great care to note that this does not necessarily entail state sovereignty for every people, nor does it limit the duties of international responsibility. Indeed, global solidarity and the universal common good were central themes in his social teachings. ${ }^{31}$

Whereas John Paul's teachings on human rights and solidarity were notably forceful and pervasive, it was with respect to democracy that he broke a great deal of new ground. No longer invoking at all the traditional neutrality of the Church with respect to political systems, in his 1987 encyclical, Sollicitudo Rei Socialis, he affirmatively and clearly called for democracy (in which he included by definition the rule of law and respect for human rights) as the best alternative to corruption and authoritarianism. Several years later, in his i 99 I encyclical Centesimus Annus, John Paul II stated a preference for democratic systems forcefully: "The Church values the democratic system inasmuch as it ensures the participation of citizens in making political choices, guarantees to the governed the possibility both of electing and holding accountable those who govern them, and of replacing them through peaceful means when appropriate. ${ }^{~} 32$

It was not merely a formal or procedural view of democracy that John Paul endorsed. He spoke of "authentic" democracy as one that guarantees human rights, respects the rule of law, and ensures the common good. In particular, democracies must respect genuine 
human values. "A democracy without values easily turns into open or thinly disguised totalitarianism," he warned, noting that "even in countries with democratic forms of government, these rights are not always fully respected." ${ }^{33}$ The ultimate "synthesis of these rights" is religious freedom, "understood as the right to live in the truth of one's faith and in conformity with one's transcendent dignity as a person." Thus, he emphasized from the beginning of his pontificate that "religious freedom is simply one facet of the single prism of freedom, which is an essential constitutive element of an authentically modern and democratic society. This means that ... a State cannot claim to be 'democratic' if it opposes religious freedom in any way whatsoever." 34

In sum, we can see in four centuries of Catholic thought on human rights, the rule of law, state sovereignty, and democracy both an essential continuity as well as profound doctrinal and philosophical developments, especially in the last century and most of all after Vatican II. ${ }^{35} \mathrm{We}$ can see, too, both the convergence and the abiding tensions between Catholic thought and the norms that are found in domestic and international law and institutions.

A concise synthesis of both themes and their application to two salient issues of global law and politics today can be found in Pope Benedict XVI's address to the United Nations in April 2008. ${ }^{36}$ Benedict first noted that the objectives of the United Nations represent an important part of the common good of the human family and reiterates the Church's call for a "greater degree of international ordering." The basis for this endorsement, however, is clearly the universal responsibility for the common good. Citing Vitoria, Benedict affirmed the unity of the human family and derived from it a responsibility on the part of states to protect their own and others' populations from grave violations of human rights and from humanitarian crises. The "responsibility to protect" is a controversial idea in international law and politics today, criticized for being at odds with the sovereign equality and autonomy of states or with a legalistic formalism that insists that nations may use military force only in self-defense 
or with the UN Security Council's prior authorization. Benedict's clear affirmation of the legitimacy of the "responsibility to protect" is consistent with a tradition that sees the common good, rather than sovereignty, as the foundation of political authority. Such intervention "should never be interpreted as an unwarranted imposition or a limitation on sovereignty," he made clear.

His treatment of a second issue, human rights, revealed even more acutely the Catholic Church's simultaneous convergence and persistent difference with prevailing secular conceptions and practices. Celebrating the sixtieth anniversary of the Universal Declaration of Human Rights, Benedict affirmed that "human rights are increasingly being presented as the common language and the ethical substratum of international relations," and he asserted that "the universality, indivisibility and interdependence of human rights all serve as guarantees safeguarding human dignity." He quickly added, however, that the only genuine foundation for human rights is the natural law "inscribed on human hearts and present in different cultures and civilizations," and that human rights must be understood to be "measures of the common good." The common good that rights help accomplish, he warned, will not be achieved through correct procedures or the formalities of legality, but requires that rights remain rooted in "unchanging justice" and "the unity of the human person," rather than in positivistic or utilitarian conceptions of law and society. The most important guarantor that human rights are indeed oriented toward the integrity of the human person in all of its factors is the respect for religious freedom, "understood as the expression of a dimension that is at once individual and communitarian - a vision that brings out the unity of the person while clearly distinguishing between the dimension of the citizen and that of the believer."

Benedict concluded these reflections with a point drawn from his own encyclical, Spe Salvi, that "every generation has the task of engaging anew in the arduous search for the right way to order human affairs." ${ }^{37}$ Church teachings in these areas are to be read and 
practiced with attentiveness to concrete realities, through the exercise of prudence and practical reason, and cannot be considered merely as abstract doctrines. This brings us to the second portion of our article: a consideration of the Church's practical experience of advancing norms of human rights and democracy once it had embraced them clearly in the latter twentieth century.

\section{Convergence and Conflict in Practice ${ }^{38}$}

Here again, we find ambivalence. The Church's convergence with liberal norms found in democratic states and international institutions formed an efficacious synergy insofar as it enabled it to take up opposition to and to collaborate closely with other secular actors in opposing regimes that cruelly violated these norms: communist regimes, right-wing military dictatorships, and sui generis violators like South Africa's apartheid regime. But the Church also encountered tensions in its advancement of these norms. Some of these arose in the Church's confrontation with authoritarian regimes, in which some national churches were resistant to the new teaching or were too dominated by dictatorships to voice them. Other tensions surfaced in the Church's relationship to democracies, both longstanding and newly established ones, and to international institutions like the European Union and the United Nations. These emanated from differences like the ones described above between the Church's interpretation of human rights and democracy, derived from its own conception of the common good, and interpretations articulated and practiced in the constitutions and policies of states and international institutions.

The Church's endorsement of human rights and democracy at Vatican II proved to be a powerful motor of change in the latter decades of the twentieth century. One of the most significant global trends of this period was what political scientist Samuel Huntington has called the "Third Wave" of democratization - a wave of some eighty countries that made a transition from authoritarian- 
ism to democracy. ${ }^{39}$ Observing the transitions between 1974 and I 990, Huntington found that roughly three quarters of these were majority Catholic in their populations. The Third Wave was "overwhelmingly a Catholic Wave," he wrote. Beginning in Portugal and Spain in the I 970 s, spreading across Latin America and the Philippines in the 1980s, the Catholic Wave peaked in Poland in 1989 , sparking the spate of Eastern European revolutions against communist rule. After the end of the Cold War, the wave continued in settings like East Timor and Ukraine's Orange Revolution of 2004.

The Church's new teachings were arguably an important cause of the Catholic Wave of democratization. They demonstrably led national Catholic churches, often in alliance with the Vatican, to defy communists and caudillos, a defiance that, combined with other factors, led to transitions to democracy. Leaders and laity protested publicly through statements and demonstrations; they organized in underground cells; they celebrated masses and other liturgies with a partly political intent; they joined forces with unions, parties, journalists, and non-governmental organizations within and outside of national borders; and they sometimes evoked the Church's historical place in a country's national identity so as to delegitimize regimes that oppressed it.

Through such defiance, the Church's convergence with the organizing principles of the modern liberal state became a potent force for justice. Yet, the transmission of Vatican teachings to national settings has not been universally smooth. Whereas some national churches opposed dictatorships inspiringly and memorably, others remained cozy with autocrats or stunted in their defiance. A brief global survey of the Catholic Wave reveals this variation.

In Europe, two forms of Catholic opposition corresponded to two different forms of dictatorship. In Portugal and Spain, the Church became a force for democracy by withdrawing its support for military dictatorships that it had helped to legitimize for several decades, most vividly that of Spain's Generalissimo Francisco Franco. Its authoritarian opponents in Eastern Europe were com- 
munist regimes that exercised dictatorial control over the governance and practice of churches. These regimes the Church opposed as a dissident, most memorably in Poland, where it was supported by its charismatic native son, John Paul. Church opposition was also strong in Lithuania, but was comparatively moderate in Czechoslovakia and weak in Hungary.

In Latin America, the Church had once been an integral partner to colonial states but eventually became disestablished in virtually every state on the continent in the nineteenth or early twentieth century. ${ }^{40}$ When most of Central and South America came (or persisted) under the control of military dictatorships in the 1960 s and I 970 s, some national Catholic churches became powerful voices of opposition and contributors to the wave of democratization that occurred in the I 980 s: in Brazil, Chile, El Salvador, Nicaragua, Guatemala, and in Mexico, where it was an anti-clerical leftist autocracy that the Church faced. Other churches, however, in Argentina, Paraguay, and Uruguay, remained closely allied with dictatorships and did little to support these countries' transitions to democracy in the 1980 s.

A similar pattern of opposition to a government with which the Church was once a partner occurred in the Philippines, where the Church helped to lead the "people power" protests that overthrew Ferdinand Marcos in 1 986. Elsewhere in Asia, the Church was also a strong democratizer: in South Korea, it joined Protestant Churches in mounting public protests against the dictatorship of President Park Chung Hee; in East Timor, a Church that was once a partner to the colonial Portuguese state became, under the leadership of Bishop Carolos Ximenes Belo, a key leader in the struggle for independence from Indonesia and the establishment of democracy.

Finally, Africa also provides rich examples of both strong and weak democratizers among Catholic churches. In Malawi, for instance, the 1992 national pastoral letter of that country's bishops, "Living Our Faith," leveled public criticism at the one-party dictatorship of Hastings Banda and became pivotal in his downfall. 
Catholic churches in Kenya, Congo, Ghana, Zimbabwe, Mozambique, South Africa, and Zambia were likewise instrumental for democratization. In Uganda and Rwanda, by contrast, the Church was collaborationist or febrile; some Rwandan clerics were even implicated as perpetrators in the genocide of I 994 .

What explains these differences? We propose two factors that enabled or hindered the Church's advancement of its teachings of human rights and democracy and that account in good part for why the Church in Rome's convergence with norm of human rights and democracy was strong in some locales but weak in others.

The first may be thought of as "political theology," the set of ideas that any religious person or organization holds about legitimate political authority. The strongest democratizers were those national churches in which the political theology of the Church's teachings on human rights and democracy was held most widely and deeply among all of its members, but especially its bishops. In some churches, such as in Chile and Brazil, these ideas had taken root and spread even prior to the Council and were then empowered by it.

The second explanatory factor, coined "differentiation" by sociologists of religion, describes the degree of mutual autonomy between churches and states in their basic legal authority. "Differentiated" church-state relationships are ones in which churches are not established, remain unrestricted in their governance and practice, and do not themselves hold standing prerogatives in the state. By contrast, undifferentiated or "integrated" relationships are ones characterized by low autonomy in all of these dimensions. The most effective democratizers were churches acting from a high level of differentiation from the state, ones that neither collaborated closely with nor were altogether suppressed by authoritarian regimes. Their differentiated position provided what George Weigel has called "moral extraterritoriality," an island redoubt of free thought and speech from which it could speak and organize in opposition. ${ }^{41}$

Through four different sequential patterns, political theology and differentiation shaped national churches' pursuit of democra- 
tization. The first consists of countries were the Church had been institutionally differentiated from the state for several decades prior to Vatican II. At some later point, a liberal democratic political theology characteristic of the Council rose and spread through its ranks and led it to become a democratizer. This pattern may be summarized as differentiation then ideas. Its best exemplar is the Polish Catholic Church, whose differentiation from the state dates back to its period of partition between I 795 and I9I 8 and persisted through communist rule after World War II. Following the Council, the Polish Church became an advocate not just of its own autonomy but of the principles of human rights and democracy, themes that John Paul strongly resounded. ${ }^{42}$ The geographically proximate Lithuanian and Ukrainian Catholic Churches fit this pattern as well, as does the South Korean Church. The same pattern obtains in Latin America, where virtually all national churches were disestablished - and institutionally differentiated — by 1 925 , many of whom hosted a growth in liberal democratic political theology at some later date, in all cases a growth that the Council greatly accelerated. The most ardent proponents of democracy were those churches in which the new political theology became lodged earliest, widest, and deepest. It was the Brazilian church, where liberal democratic ideas were held widest, that took up democratic opposition earliest and strongest - lay movements, base communities, and a coalition (but not a unanimous one) of the nation's bishops. Next came the Chilean Church, where the new thinking also took hold comparatively early, wide, and deep, and whose bishops, though initially divided over General Augusto Pinochet's rule, were united against him by 1976. Churches in Nicaragua, El Salvador, Ecuador, Panama, Bolivia, and Guatemala became supporters of democracy later, once liberal democratic ideas gained ground there. ${ }^{43}$

In a second pattern, national churches remained undifferentiated from their states right up to Vatican II, whose new thinking then brought them to separate themselves from their states. The sequence here was ideas then differentiation. By i 97 I, the bish- 
ops of the Spanish Church called for the separation of church and state, asked clergy to step down from government positions, and (in a majority vote) publicly repented for the Church's role in the civil war of the I 930 . Their opposition proved a major source of democracy after the death of Franco in 1975 . The democratization of Portugal just prior to that of Spain was also encouraged by a Catholic church where the Council's political theology encouraged a majority of bishops to withdraw their support from an authoritarian regime. In the Philippines, too, the Catholic Church that encouraged the overthrow of Marcos in 1986 under the leadership of Jaime Cardinal Sin was one that had once been integrated with the regime but then expanded its oppositional stance more and more strongly as its members took on the teachings of the Council more and more widely. ${ }^{44}$

A third pattern is one in which differentiation and new ideas arose in a national church at roughly the same time and where it is difficult to say how one influenced the other. It might be called ideas and differentiation. Many opposition movements in Africa during the I 980 os and I 990 s fit this description. Through episcopal pronouncements, politically charged religious ceremony, organization and lobbying, the support of papal visits, and collaboration with Protestant churches and political parties, national churches in Kenya, Congo, Ghana, Malawi, Zimbabwe, Mozambique, South Africa, and Zambia opposed postcolonial authoritarian regimes. In all of these cases, the Church's agitation for democracy came after the rise of institutional differentiation and the reception of the Council's political theology of human rights and democracy. ${ }^{45}$

The fourth and final pattern involves those national churches that never or only feebly opposed dictatorships. True to the argument, these were far less autonomous from the state than the vigorous democratizers and contained far less support for liberal democratic political theology. The Czechoslovakian Catholic Church, which came to oppose its own communist regime only in the mid-1980s and much less energetically than did the Church in Poland and Lithu- 
ania, was also comparatively less independent in its governance, less connected with opposition groups, and, at least in the Czech portion of the state, far more alienated from the loyalties of the nation, which bore memories of Habsburg suppression of separatism during the Reformation era. Apart from the solitary opposition of József Cardinal Mindszenty, the Catholic Church in Hungary resisted Communism even more feebly, and was even more dominated in its governance and slow to accept Vatican II's teachings. In Africa, the churches that failed to pursue democracy strongly - those in Angola, Cameroon, Uganda under the Museveni regime in I 986, and Rwanda-failed to achieve differentiation, remaining either dominated, as was the Angolan Church under a Marxist regime, or strongly tied to the regime, as was the Church in Rwanda, and espoused a neutral political theology, open to supporting a wide variety of regimes. ${ }^{46}$ These negative examples, too, point to the political factors that assist or hinder the Church's promotion of its teachings on human rights and democracy, the fruit of the convergence with the modern state that took place progressively throughout the twentieth century.

In the years after Vatican II, the Church also manifested ambivalence in its relations with existing constitutional democracies, the European Community/Union, and the United Nations. Its ambivalence here was more straightforward, emanating from the conceptual divergences with secularism described in the first part of our article. In broad principle, the Church continued to support strongly all of these institutions. After the revolutions of 1989 , John Paul continued to voice support for democracy - and democracies. Though his support was global in its reach, above all he championed his native Poland, seeing in this overwhelmingly Catholic nation a potential model of a morally and spiritually well-grounded democracy. He also continued the tradition of papal support for European federation, which took the form of the European Union in 1993. He hoped that common European institutions would be the carriers of a culturally united European civilization based on democracy, human rights, religious freedom, and the dignity of the person and the 
family, the same vision that he had wielded against communist governments in Eastern Europe. ${ }^{47}$ Finally, in numerous statements and speeches, John Paul continued the papacy's support for the United Nations, both its traditional mission as well as new endeavors like humanitarian intervention.

But if John Paul, other postconciliar popes, and most national level bishops supported these forms of institutions and encouraged them to manifest the common good that the Church taught, they also at times found these institutions wanting in just this regard. The Church criticized democracies in North and South America, Europe, and Australasia most consistently and vociferously over policies regarding abortion, divorce, euthanasia, stem cell research, cloning, and same-sex unions. Though it often addressed itself to issues like war, immigration, and the security of the poor as well, its statements, stratagems, and activism over the former set of issues most vividly manifested the divergence between its own conception of freedom, grounded in its teachings about the human person, and a secular liberal freedom of self-definition and subjective autonomy.

Though this divergence played itself out in manifold political settings, it is hard to find a better showcase for it than in postcommunist Poland. John Paul's vision of Poland as a light for Europe, a similar vision held by Poland's bishops - communist era Stefan Cardinal Wyszyński had called Poland the "Christ of Nations" for its redemptive role in European history - combined with the prestige that the Church derived from its heroic opposition to communist rule, gave the Church both an interest in and influence for promoting its conception of democracy on this particular turf. ${ }^{48}$ In the early years after the fall of communism, then, the Polish Church sought legal protection for the human person from the moment of conception and religious education in the public schools; a concordat with the Vatican that guaranteed its right of internal governance and strong prerogatives in education, marriage, and civil society activities; and a constitution that explicitly referenced God and the Church's role in the nation's history, that established God's "exist- 
ing and unchangeable law" as the basis of the state and superior to the constitution itself, that declared marriage to be between one man and one woman and that avoided the language of separation of church and state. But in this embryonic electoral democracy, the Church encountered competition from parties whose social vision was more reminiscent of the western half of the continent, the very region that the Church wanted Poland to influence and evangelize. Opposition was especially fierce from 1993 to 1997 under the government of the Democratic Left Alliance (DLA), a party that included former communist leaders and that sought to liberalize abortion laws and opposed the terms of the concordat. In the end, the Church's efforts were partially successful. The bishops were vexed that the final draft of the constitution did not contain the language about God, God's law, or the protection of human life from the moment of conception that they had wanted. But the document did contain a traditional definition of marriage, language about the protection of life that the Constitutional Tribunal would later leverage in 1997 to overturn a liberalized abortion law passed by the DLA, several references to God, and an endorsement of the concordat, which, signed in 1993 between Poland and the Holy See, was itself quite favorable to the Church's platform. Even in a state where the Church is uniquely influential, then, it clashed vigorously with partisans of a more secular conception of rights and democracy, though not without victories.

Similar lines of contention configured debates between the Church and the European Union in the early 2000 s. Averring that the Union is a promoter not just of a free market and efficient business transactions in a globalized world but also of a European cultural unity that is ultimately rooted in Christianity, the Church publicly took issue with the omission of Christianity in the preamble to the draft constitution of the European Union in 2003. Far from aiming to reestablish Catholicism as Europe's religion, John Paul argued that Christianity merited mention on account of its historic contribution to democracy, human rights, religious freedom, the 
secular state, pluralism, and, in his words, "a melting pot of different cultures" on the European continent. ${ }^{49}$ But Valéry Giscard d'Estaing, former president of France and chairman of the drafting committee for the EU Constitution, demurred, agreeing only to the preambular mention of Europe's religious heritage alongside mentions of ancient Rome and Greece, the Enlightenment, and the French Revolution. ${ }^{50}$ The Church also expressed opposition to a trend toward endorsing same-sex unions in EU policies. The European Parliament reciprocated when it rejected the nomination of Rocco Buttiglione, a Catholic Italian politician who adheres to the Church's teachings on sexuality, as European Commissioner for Justice and Home Affairs. Perceiving this cultural momentum, some right-wing Polish Catholics even opposed democratic Poland's entry into the European Union, fearing the body's influence on Poland's own politics. The consensus of Polish bishops, though, supported Poland's entry, hoping that the influence would run in the other direction.

Finally, the Church has fought not a culture war, but certainly some cultural battles, against the United Nations. It fought these, again, on issues where the Church's foundation for rights yielded different conclusions than those of secularists.

At both the UN's International Conference on Population and Development in Cairo in 1994 and its Fourth World Conference on Women in Beijing in 1995, the Church strongly affirmed the meetings' basic goals of economic development and the equality of women but opposed abortion and artificial contraception as means of birth control as well as denials of the dignity of women's vocation to family and motherhood. As with disputes in the context of democratic states and the European Union, the Church took issue not with human rights and democracy themselves but with manifestations and interpretations that diverged from its own teachings. 


\section{Conclusion}

As Pope Benedict XVI's December 2006 address to the Roman $\mathrm{Cu}-$ ria suggests, the Catholic Church's relationship to human rights and democracy has long been ambivalent. The Church endorsed human rights as early as its sixteenth century pronouncements on colonization in the New World and with accelerated force in its modern encyclicals beginning in I $89 \mathrm{I}$. Through an extended dialogue with the modern world, including proponents of the Enlightenment, and through the parallel evolution of the state and international institutions, the Church's teaching converged more and more with the norms of human rights and democracies found in these secular institutions. This convergence was consolidated at Vatican II. But Vatican II did not dispel differences between Catholic and secular articulations of human rights and democracy, either in theory or in practice. In numerous (but far from all) instances, national Catholic churches have come to oppose dictatorships in the very name of human rights and democracy. In the case of long established or newly minted democracies, entirely new forms of divergence between the Church's teachings and democratic practice have arisen. Such divergence is likely to persist, even as the Church is likely to remain enthusiastic about the core norms of constitutional democracies, the European Union, and the United Nations.

Though the Church's teaching has evolved - or, better yet, "developed," to use the concept that John Henry Newman articulated in the nineteenth century and that the Church embraced in the twentieth - there is nevertheless continuity and consistency behind the Church's ambivalent stance toward human rights, democracy, and the modern state. The common thread running through centuries of teaching and practice consists of the Church's commitment to upholding the transcendent dignity of the human person and affirming that the legitimacy of any political authority lies in its accountability to the common good, understood as a moral order grounded in this human dignity, rather than in state sovereignty or even democracy as such. 


\section{Notes}

I. Pope Benedict XVI, http://www.vatican.va/holy_father/benedict_xvi/speeches / $2006 /$ december/documents/hf_ben_xvi_spe_2006 I 22 2_curia-romana _en.html.

2. Thomas Aquinas, for example, considered law to be "nothing else than a rational ordering of things which concern the common good." Summa theologiae (ST) I-II, q. 90, a. 4 .

3. See J. Morris, "The Contribution of Francisco de Vitoria to the Scholastic Understanding of the Principle of the Common Good," The Modern Schoolman, 78 (November 2000): 9 .

4. Brian Tierney, The Idea of Natural Rights: Studies on Natural Rights, Natural Law and Church Law, 1150-1625 (Atlanta, GA: Scholars Press, I 997), 255, 272-87.

5. Perhaps the best known example is the papal bull Sublimis Dei, promulgated by Paul III in I 537 , which declared that "the Indians . . . may and should, freely and legitimately, enjoy their liberty and the possession of their property; nor should they be in any way enslaved; should the contrary happen, it shall be null and have no effect."

6. Romans I $3: \mathrm{I}-7$

7. Quoted in Ibid.

8. Michael Burleigh, Earthly Powers: The Clash of Religion and Politics in Europe, from the French Revolution to the Great War (New York: HarperCollins, 2005), 67-I I I.

9. Pope Pius IX, Syllabus of Errors, Nos. I 5 and 8o, available at http://www.papalencyclicals.net/Piusog/p9syll.htm.

I ○. Pope Pius VI, Apostolic Letter Quod Aliquantum, in Recueil des allocutions consistoriales, encycliques, et autres lettres Apostoliques des souverains Pontifes Clément XII, Benoit XIV, Pie VI, Pie VII, Léon XII, Gregoire XVI, et Pie IX (Paris: Librairie Adrien Le Clere et Cie., I 865$), 45,53$.

I I. Pope Leo XIII, Rerum Novarum, On Capital and Labor, 7 and 22, available at http: / / www.vatican.va/holy_father/leo_xiii/encyclicals/documents/hf_l-xiii_ enc_i 505 I 89 I_rerum-novarum_en.html.

I 2. See, for instance, Pope Pius XII, "Con Sempre Nuova Freschezza," Cath. Mind 4 I (January I 943): 45-60.

I 3. See Paolo G. Carozza, "From Conquest to Constitutions: Retrieving a Latin American Tradition of the Idea of Human Rights," Human Rights Quarterly 25 (2003): 28 I .

I 4. See John F. Pollard, Benedict XV:The Pope of Peace (London: Continuum, I 990).

I 5. See Raymond F. Cour, "The Political Teachings of Pope Pius XII," Rev of Politics 22 (October I 960): 482,484 .

I6. See, for instance, Pope Pius XII, "Gravi ed ad un tempo," Cath. Action 2 I (January I 949): 3, I 8-20.

I 7. See generally Michel Schooyans, Democracy in the Teachings of the Popes (Proceed- 
ings of the Workshop on: Democracy, I 996), available at http://www.vatican.va /roman_curia/pontifical_academies/acdscien/documents/DEMOCRACY.pdf.

I 8. Pope Leo XIII, Diuturnum, 6 and 7, available at http://www.vatican.va/holy _father/leo_xiii/encyclicals/documents/hf_l-xiii_enc_2906 I 88 I_diuturnum _en.html

1 9. Pope Pius XII, "Benignitas et humanitas," Cath. Mind 43 (Feb. 1945): 65-77.

20. Regarding Monnet's "private, pragmatic, complex ... attitudes to religion," see François Duchêne, Jean Monnet: the first statesman of interdependence (New York: Norton, 1 994), 56 .

2 I. See Brent F. Nelsen, James L. Guth, and Cleveland R. Fraser, "Does Religion Matter? Christianity and Public Support for the European Union," in Religion in an Expanding Europe, ed. Timothy A. Byrnes and Peter J. Katzenstein (Cambridge: Cambridge University Press, 200 I).

22. Pope John XXIII, Pacem in Terris, available http://www.vatican.va/holy_father /john_xxiii/encyclicals/documents/hf_j-xxiii_enc_I I 041 963_pacem_en.html.

23. Second Vatican Council, Dignitatis Humanae, available at http://www.vatican.va /archive/hist_councils/ii_vatican_council/documents/vat-ii_decl_r 965 I 207_ dignitatis-humanae_en.html.

24. Second Vatican Council, Gaudium et Spes, available at http://www.vatican.va /archive/hist_councils/ii_vatican_council/documents/vat-ii_cons_I 965 I 207 _ gaudium-et-spes_en.html.

25. The reverse may not be true. The world has many "illiberal democracies" characterized by elections but by low levels of individual rights and liberties. See Fareed Zakaria, The Future of Freedom: Illiberal Democracy at Home and Abroad (New York: W.W. Norton \& Co., 2004). For a definition of democracy that includes human rights, see Juan J. Linz and Alfred Stepan, Problems of Democratic Transition and Consolidation: Southern Europe, South America, and Post-Communist Europe (Baltimore: Johns Hopkins University Press, I 996).

26. Pope Paul VI, Populorum Progressio, available at http://www.vatican.va/holy_father /paul_vi/encyclicals/documents/hf_p-vi_enc_2603 I 967 _populorum_en.html.

27. Pope PaulVI, Octagesima Adveniens, No. 47, available at http://www.papalencyclicals .net/Paulo6/p6oct.htm.

28. Pope John Paul II, Redemptor Hominis, No. i 7 , available at http://www.vatican.va /holy_father/john_paul_ii/encyclicals/documents/hf_jp-ii_enc_0403 1979 _redemptor-hominis_en.html.

29. Pope John Paul II, Address to the United Nations, available at http://www .vatican.va/holy_father/john_paul_ii/speeches/ i 995/october/documents/hf _jp-ii_spe_05 I 0 I 995_address-to-uno_en.html.

30. Pope John Paul II, Evangelium Vitae, i 8, available at http://www.vatican.va/holy _father/john_paul_ii/encyclicals/documents/hf_jp-ii_enc_2503 I 995 _evange lium-vitae_en.html.

3I. See especially Pope John Paul II, Sollicutudo Rei Socialis, available at http:// 
www.vatican.va/holy_father/john_paul_ii/encyclicals/documents/hf_jp-ii _enc_30 I 2 I 98 7_sollicitudo-rei-socialis_en.html.

32. Pope John Paul II, Centesimus Annus, 46, available at http://www.vatican.va/holy_ father/john_paul_ii/encyclicals/documents/hf_jp-ii_enc_o I 05 I 99 I_centesimus -annus_en.html.

33. Pope John Paul II, Veritatis Splendor, 47, available at http://www.vatican.va/holy _father/john_paul_ii/encyclicals/documents/hf_jp-ii_enc_0608 I 993 _veritatis -splendor_en.html.

34. Pope John Paul II, Address to the 69th Conference of the Interparliamentary Union, http://www.vatican.va/holy_father/john_paul_ii/speeches/ I 982 /september /documents/hf_jp-ii_spe_198209 I 8_unione-interparlamentare_it.html.

35. Of course, the gradual evolution that took place over a century of Catholic thought is not fully captured merely by reference to papal teachings. For example, from the I 930 s to the I 95 os, Catholic intellectuals like Jacques Maritain and John Courtney Murray, both admirers of the American constitution, drew on the natural law tradition to develop arguments for human rights, democracy, and religious freedom. See John T. McGreevy, Catholicism and American Freedom (New York: W. W. Norton \& Co., 2003), 20I-08. Equally important were the practical experiences of Catholic social activists, labor unions, and political parties in Europe, the United States, and Latin America.

36. Pope Benedict XVI, Address of the Holy Father to the General Assembly of the United Nations Organization in New York (April I 8, 2008), available at http:// www.vatican.va/holy_father/benedict_xvi/speeches/2008/april/documents /hf_ben-xvi_spe_200804I8_un-visit_en.html.

37. Pope Benedict XVI, Spe Salvi, 25, available at http://www.vatican.va/holy_father /benedict_xvi/encyclicals/documents/hf_ben-xvi_enc_2007 I I 30 _spe-salvi _en.html.

38. This portion of the essay draws from Daniel Philpott, "The Catholic Wave," Journal of Democracy I 5 , no. 2 (2004); Daniel Philpott, "Explaining the Political Ambivalence of Religion," American Political Science Review ro3, no. 3 (2007); Daniel Philpott and Timothy Samuel Shah, "Faith, Freedom, and Federation: The Role of Religious Ideas and Institutions in European Political Convergence," in Religion in an Expanding Europe, ed. Timothy A. Byrnes and Peter J. Katzenstein (Cambridge: Cambridge University Press, 2006); Monica Duffy Toft, Daniel Philpott and Timothy Samuel Shah, God's Century: Resurgent Religion in Global Politics (New York: W. W. Norton, 20II).

39. The exact number of countries that have become democracies since the "Third Wave" began in 1974 is not clear. In his The Third Wave: Democratization in the Late Twentieth Century (Norman, OK: University of Oklahoma Press, I 99 I), Samuel P. Huntington documents 30 transitions between 1974 and 1989 . Freedom House reports that the number of "free" countries increased by I 3 from I 989 to 2004 . See Freedom House Press Release, Russia Downgraded to 'Not Free' (Washington, DC: 
Freedom House, 2004); and Freedom House, Freedom in the World 2005: The Annual Survey of Political Rights and Civil Liberties (Washington, DC: Freedom House, 2005). Democracy theorist Larry Diamond estimates that between 1974 and I996, between 36 and 77 states became democracies, depending on how one counts democratization exactly. See his "Is the Third Wave of Democratization Over? An Empirical Assessment, W Working Paper \#236, Kellogg Institute, University of Notre Dame, March 1997 .

40. Anthony Gill, Rendering Unto Caesar (Chicago: University of Chicago Press, I 998), 32 .

4I. George Weigel, The Final Revolution: The Resistance Church and the Collapse of Communism (Oxford: Oxford University Press, I 992), I 5 I .

42. Paul Mojzes, Religious Liberty in Eastern Europe and the USSR: Before and after the Great Transformation (Boulder, CO: East European Monographs, I 992), 294-99; George Weigel, The Final Revolution:The Resistance Church and the Collapse of Communism (Oxford: Oxford University Press, 1992).

43. See Jeffrey Klaiber, The Church, Dictatorship, and Democracy in Latin America (Maryknoll, NY: Orbis Books, I 998); Scott Mainwaring and Alexander Wilde, "The Progressive Church in Latin America: An Interpretation," in The Progressive Church in Latin America, ed. Scott Mainwaring and Alexander Wilde (Notre Dame: University of Notre Dame Press, I 989 ).

44. Paul Christopher Manuel, "Religion and Politics in Iberia: Clericalism, Anti-Clericalism, and Democratization in Portugal and Spain," in Religion and Politics in Comparative Perspective: The One, the Few, and the Many, ed. Ted Gerard Jelen (Cambridge, UK: Cambridge University Press, 2002), 8 I-92; Stanley G. Payne, Spanish Catholicism:A Historical Overview (Madison: University of Wisconsin Press, I 984), I 49-2 I 3 ; and Robert L. Youngblood, Marcos against the Church (Ithaca, NY: Cornell University Press, 1990).

45. See Paul Gifford, The Christian Churches and the Democratisation of Africa (Leiden, the Netherlands: E. J. Brill, I 995), Isaac Phiri, Proclaiming Political Pluralism: Churches and Political Transitions in Africa (London: Praeger, 2001).

46. See Gifford, Churches and Democratisation in Africa, Sabrina P. Ramet, Nihil Obstat: Religion, Politics, and Social Change in East-Central Europe and Russia (Durham, NC: Duke University Press, I 998), 90-I 44; Carol Rittner, John K. Roth, and Wendy Whitworth, Genocide in Rwanda: Complicity of the Churches? (St. Paul, MN: Paragon House, 2004).

47. See Michael Sutton, "John Paul II's Idea of Europe," Religion, State, and Society 25, no. I (1997).

48. We rely here especially on Timothy A. Byrnes, Transnational Catholicism in Postcommunist Europe (Lanham, MD: Rowman and Littlefield, 200 I), 29-58, esp. 37.

49. German philosopher Jürgen Habermas agreed when he commented in 2004 that "Christianity, and nothing else ... is the ultimate foundation of liberty, conscience, 
human rights, and democracy, the benchmarks of western civilization. To this day, we have no other options [to Christianity]. We continue to nourish ourselves from this source. Everything else is postmodern chatter," quoted in Christa Case, "Germans Reconsider Religion,” The Christian Science Monitor, September I 5, 2006.

50. "Pope argues for the Inclusion of Christian Roots in Constitution," September 8, 2003, www.goacom.com. Cited in Ramet, I 40. 